\title{
Yūji Muramatsu
}

\author{
$1911-1974$
}

On March 6, I974 at 5:31 A.M. Professor Yūji Muramatsu died at Kitazato hospital in Tokyo. Perhaps Japan's leading scholar on modern China, Professor Muramatsu had not only written two significant and important books, numerous distinguished journal articles, and many book reviews, several of which appeared in this journal, but he also had led a remarkable academic career, serving for two years as Dean of the Faculty of Economics of Hitotsubashi University $\left(196_{3}-6_{5}\right)$ and acting president of the same university in 1969 , the year of intense student riots throughout Japan.

Yüji Muramatsu was born on January r6, ıgı i in the city of Hachiōji of Tokyo metropolitan area not far from Hitotsubashi University where he was a student and later taught as a professor. He graduated from the Faculty of Tokyo Commercial College (changed to Hitotsubashi University after the war) in March 1933, became a teaching assistant in December 1934, advanced to lecturer in July 1935, and obtained the rank of assistant professor in December 1940 at the same university. In April $195^{\circ}$ he became full professor. In March 1962 he received his doctorate in Economics, extremely rare for one trained before the war, for his essay The Historical Materials Concerning the Landlord System in the Kiangnan during the Late Ch'ing Period. During the ig6os he lectured briefly at the College of Mexico, University of Michigan, and the University of California (Berkeley). Just before he was to retire from Hitotsubashi (1974), he began receiving acclaim for his scholarship within Japan by receiving in 1971 the 14th Special Cultural Award from the Japan Economics Library and in 1972 an award from The Japanese Academy of Scholars.

His first book Chügoku keizai no shakai taisei (The Social Organization of the Chinese Economy), published in 1949, seems to have had virtually no influence upon modern Chinese studies either in Japan or elsewhere. The analytic model underlying this brilliant work was simply too conceptually advanced for its day. This model viewed the Chinese economy between I890 and I949 as a system comprised of two separate but yet inter-related structures. The first structure, an outer web of relations made up of state fiscal and monetary institutions, various private administrative organizations of villages, clans, and gilds, and commodity markets was connected to an inner structure based upon rural families, commercial organizations, and modern and pre-modern manufacturing enterprises through certain behavioral relationships involving key elements in each of the two structures. These crucial behavioral relationships then produced certain, observable modal tendencies in the system such as an increasing fragmentation and separation of units engaged in production and distribution and a failure of these same units to achieve larger size and technological efficiency by becoming modernized. To confirm this model, Muramatsu used a wealth of statistics and the results of important field studies 
undertaken by Japanese research units and Chinese scholars during the r930s and I940s.

The book's poor reception perhaps explains why Muramatsu chose to spend the remainder of his academic career examining only key elements of that 'inner structure' such as landlord families. He obviously enjoyed the long hours required to decipher and explain the complex, obscure language of landlord bursary documents which he had found unused in archives of Japan and the United States. His research finally led to a volume being published in 1971 which is undoubtedly the definitive study of a neglected and little understood institution, the tsu-chan or landlord bursary. Kindai Könan no sōsan (The Bursaries of the Kiangnan in Modern Times) showed how the Chinese rural landowning elite who resided mainly in the cities of the Kiangnan, the country's richest region, consolidated and preserved their landholdings through an organization which had separate and rather unique powers and rights to manage scattered parcels of land and the tenants who farmed them. This magnificent work also illustrated how, even during the last quarter century of the Ching dynasty when popular dissatisfaction with the regime became widespread, these bursaries maintained effective control over landlord holdings and preserved harmony between the absentee owners and their tenants.

Yũji Muramatsu's scholarly interests ranged over a wide assortment of issues and problems: Banner land magnates and their tenants; rural rebellions such as the Taiping and Boxers; local administration during the Republican period; Chinese Communist Party land reform and economic policies. He still managed to find time to translate into Japanese two important Western works: Eugene Staley's The Future of Developing Countries (tr. in 1957) and Etienne Balazs' Chinese Civilization and Bureaucracy (tr. in 1970). This outstanding economic historian's scholarship persistently reflected a vigorous effort to advance new and luminous organizations of the facts of modern Chinese history in order to enrich and deepen our understanding of Chinese society. To this end, he achieved a most remarkable success.

University of Miami
Coral Gables

Ramon H. Myers

(2)

While familiar with the formidable scholarly accomplishments of Professor Yũji Muramatsu so ably described by Professor Myers, I would like to add a brief note on Yũji the person and on the friendship of my wife and myself with him and his wife Haneko.

Yũji Muramatsu was a man of rare and inimitable qualities. What attracted one above all was his delightful sense of humor and the deep vein of irony which lifted him above that deadly inauthentic "spirit of seriousness" which pervades so much of the academic world both here and in Japan. His scholarly work was uncompromising in its rigor and attention to detail yet he was quite capable of standing back from it and viewing it in larger contexts. It was precisely this quality in him that made it so easy to cross the cultural barrier with him. While I never pressed him about his deeper commitments, I could not help linking this quality in him with the small zen temple behind his home in Nishi Hachiöji. 
My wife and I always immensely enjoyed his visits to Cambridge and our happy excursions together to places such as Concord, Salem and Rockport. I always cherished his keen unbookish observations on American life. On the other hand, a high point of all our visits to Japan were our excursions with the Muramatsus to temples, parks, and other places of interest in the environs of Tokyo. One could hardly ask for a better guide to the beauties of Japan or a more perceptive commentator on Japanese life.

To me, Professor Muramatsu was not only a great scholar who taught me much about the complex realities of rural organization in China but a man who strengthened my faith in the ability of men to achieve mutual understanding and friendship across the still formidable barriers of cultural difference.

Harvard University

Benjamin I. Schwartz 